\title{
Using traditions in the architecture of churches in the Orenburg province of Russia
}

\author{
Elena Ponomarenko ${ }^{1 *}$ \\ 1 Russia Scientific-Research Institute of Architecture and Urban Planning Theory, History and \\ Samara State Technical University, 443001, 244, Molodogvardeyskaya st., Samara, Russia
}

\begin{abstract}
The subject of this paper seems to be important due to the everincreasing interest in architectural traditions of Russia's regions. The purpose of the article is to identify the characteristic features of the architecture of modern wooden temples in the territory of The Orenburg province of the 19th century. The key approach I chose for this study was historical architectural analysis and integration of data from archives and field surveys. A novel systematic analysis of the evolution of church design in the region since ancient times till nowadays is offered. For the first time, a study is made of churches building based on 'model church design projects for Orenburg the Orenburg defence lines' and exemplary albums. Descriptions and analyses of the region's lesser known little known specimen of religious architecture are introduced for the scientific use based on the author's own in situ investigations. Many archival materials from Russia's central and regional repositories are considered and published at for the first time. Key properties of modern region Eastern Orthodox churches built in different architecture styles are formulated and classified.
\end{abstract}

\section{Introduction}

Wooden architecture is one of the most significant and outstanding manifestations of the artistic and construction culture of the Russian people. Until the end of the 10th century, there were no stone churches in Russia. There is a proverb that architecture is the soul of the people, embodied in stone. However, in Russia for a long time the soul of the people was embodied in wooden buildings.

The urgency of the subject is determined by the fact that regional independence and the role of regions in Russia have been steadily growing in scope and nature, so that key findings of this study should be crucially important for preservation and revival of historical environment in various country's settlement. Another focus of the increasing interest have been recently the cultural traditions of various population groups in the Orenburg province.

The main source of data for the writing of this paper was the survey of territories in the geographic area today known as the Orenburg and Chelyabinsk regions, i.e. the former Russian imperial province of Orenburg, within the boundaries of XIX c. territorial division. Available materials in central and local archives and museums have been analysed, among

\footnotetext{
* Corresponding author: evpon@mail.ru
} 
them documents from the Berg-Collegium (Ministry of Mining) and the Senate, the Mining Department, the Office of General Directorate for Plants and Factories, and the Mining Bureaus in the cities of Perm and Orenburg. System approach has been selected as the key methodological principle for the study. The This territory being a multi-national region of Russia, considerable attention is to be paid to the problem of historical architectural analysis based on the concept of social ecology. This framework entails an ethical parameter which allows to ensure church architecture continuity in its properties and characteristics.

Most actively, the Orenburg Diocese churches and temples were studied in late XIX and early XX c.; however, a growing interest in this subject is seen recently. First and foremost, two issues of N.V. Chernavsky's work titled 'The Orenburg Diocese in its past and present' [1] dated back to the pre-Soviet period. This is an extensive and very detailed history of Russian Orthodoxy, along with data on the foundation and development of churches and monasteries [2]. The book by I.I. Krechetov [3] is devoted to the founding, designing and describing churches based on archival documents available at that time.

Important statistical data on the architecture and condition of churches at that time can be found in the works of geographers and historians of the Russian Cossack Host: P.I. Rychkov [4], P.S. Pallace [5], L.S. Sukhodolsky [6], I.I. Archangelsky [7], V.M. Cheremshansky [8], R.G. Ignatyev [9], F.M. Starikov [10]. There were individual church and monastery descriptions by monks, for instance, by R.A. Budrina [11].

The study methodology is based on the complex historical and architectural investigation of the Orthodox churches. A systematic approach involves the use of historical-genetic, architectural and urban planning analysis (typological, stylistic analysis). It is particularly important that this approach takes into account many aspects of national, religious, ethnic identity of heritage. Peculiarities of a multi-national region's development is what demands more attention to historical architectural analysis based on the notion of social ecology. The main method of research is the historical and architectural analysis and generalization of archival materials and data obtained in situ. Many materials describing monuments, archival sources introduced for the scientific use for the first time.

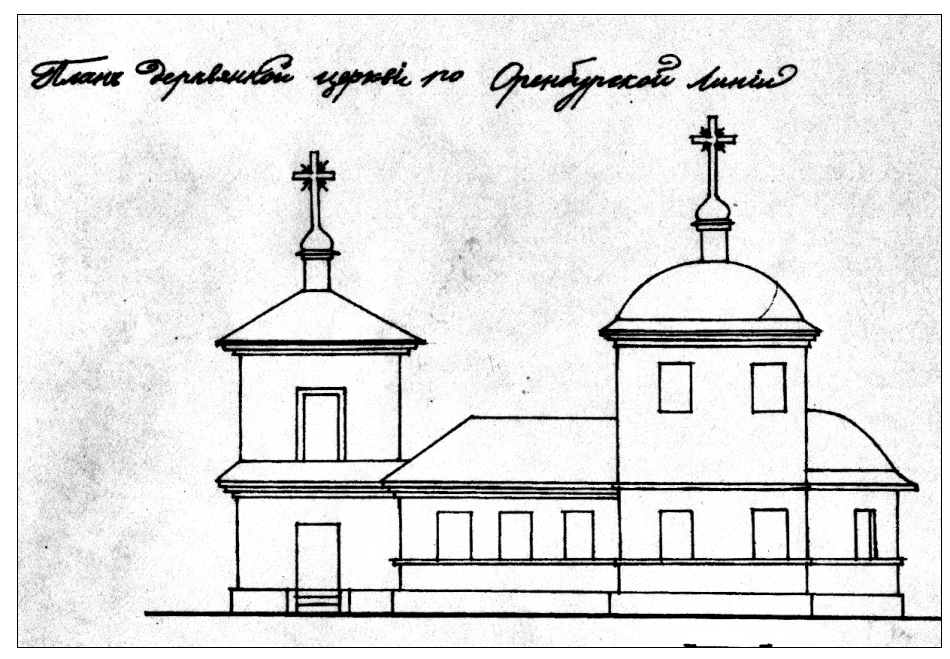

Fig.1. Exemplary wooden church designed for the Orenburg Defence Line: façade

The analysis of modern urban settlements architecture in Russia has drown us to a conclusion that currently it is in the formative stage of its evolution. 


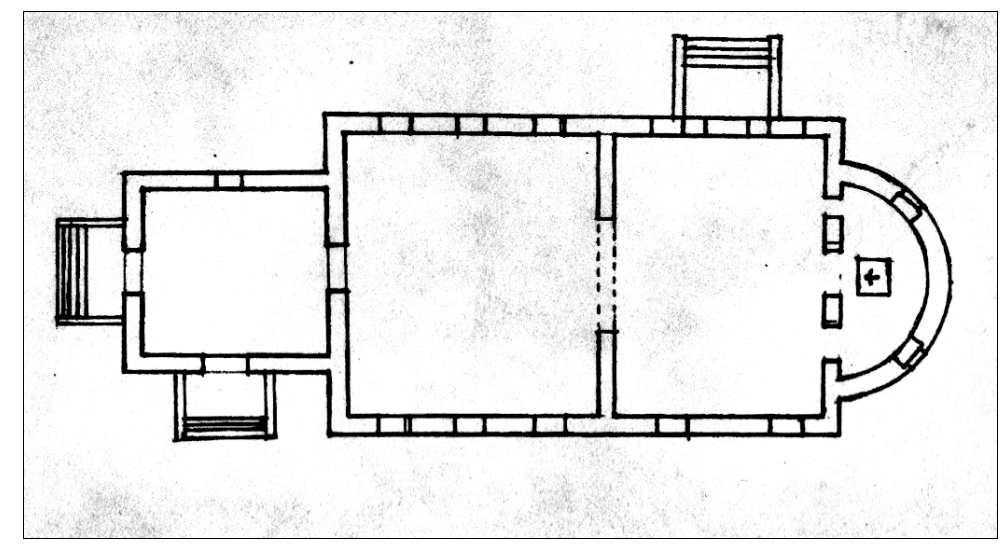

Fig.2. Exemplary wooden church designed for the Orenburg Defence Line: ground plan

Early XXI c. is a period when professional architects once again came to be aware of the role of regional tendencies in architecture. Regional architecture is none the less important than the metropolitan one because the former can be called 'mass architecture', which reflects in itself the whole picture of the country's development.

\section{Results}

The project design and erection of churches, specifically in local villages, was conducted not by professional architects having a university degree, but by crews of masons invited form the Dalmatov Monastery or from central Russia's regions. The axial church design was very popular, with all the key rooms of the church arranges sequentially.

A typical project of this type was the Draft of a wooden church for the Orenburg Defence Line [12]. From the point of view of its aesthetics, this is a very typical religious building made of wood in Russia's deep hinterland. Along the main axis there were sequentially arranged: narthex superimposed by a bell-tower, refectory, the elevated main space of the church (dais), and the altar. The refectory and the main room of the church made up a single log structure (Fig. 1, 2).

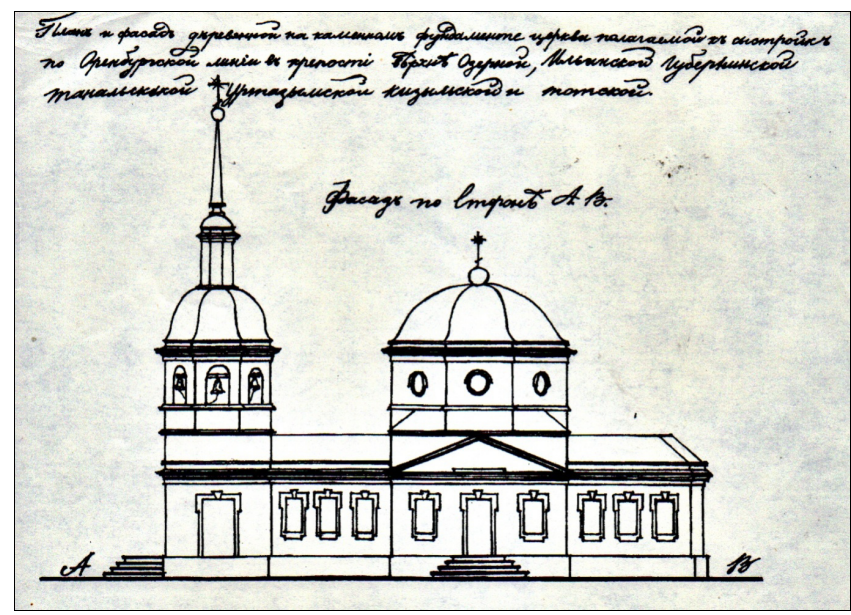

Fig.3. Exemplary wooden church for the Orenburg Defence Line, on a stone foundation: façade 
Another church building project for the fortresses of the Orenburg Defence Line has a similar design. Besides the main longitudinal axis, the ground plan of the church has a transverse axis perpendicular to the former [13]. The northern and southern entrances to the building form it (Fig. 3). The entrances are adorned with powerful triangular pediments; the windows have surrounds with protruding, accentuated top-stones (Fig. 4).

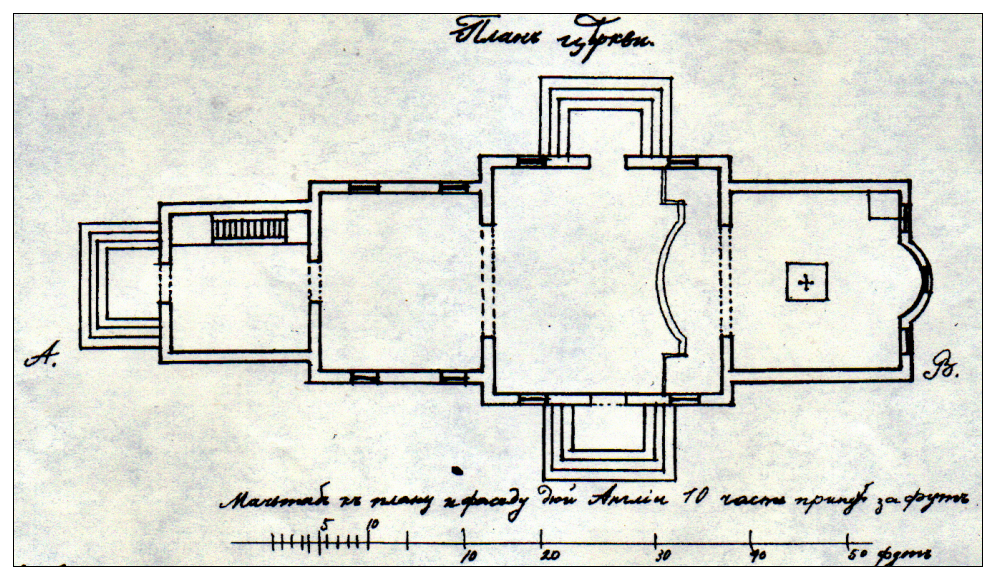

Fig.4. Exemplary wooden church for the Orenburg Defence Line, on a stone foundation: ground plan

The second quarter of XVIII c. was the time when large-scale shaping of architectural and urban planning legacy of the Russian state began; at the same time regular re-planning of largest urban settlements and re-building (in stone) of their respective central architectural ensembles started only as early as the first half of XIX c. Obviously, there had been earlier attempts at adopting and developing regular town-planning principles in the region. For instance, in commentaries to the town plan of Chelyabinsk in 1784 it was demanded to 'build houses in regular lines'. In the centre of the town it was permitted to erect only 'masonry civic houses', whereas public establishments had to be built according to 'approved facade designs and the layout of rooms' [14].

Early XIX c. was marked by a rising concern of governmental officials for the development of ecclesiastical architecture in the frontier regions of the country. In Sinodal edicts of 1826 and 1828, it was prescribed that 'generally, churches and cathedrals in the country should be built according to ground plans, designs and projects in compliance with architectural rules and canons' [15]. Ecclesiastical architecture in this period came to be a symbol both expressing and asserting Russian rule and domination on its territories adjacent to the borders. A regular town/building plan and an exemplary project thereof were the key transmitters of this policy. With this purpose in mind, projects and drawings were made in the metropolis describing model church designs. 


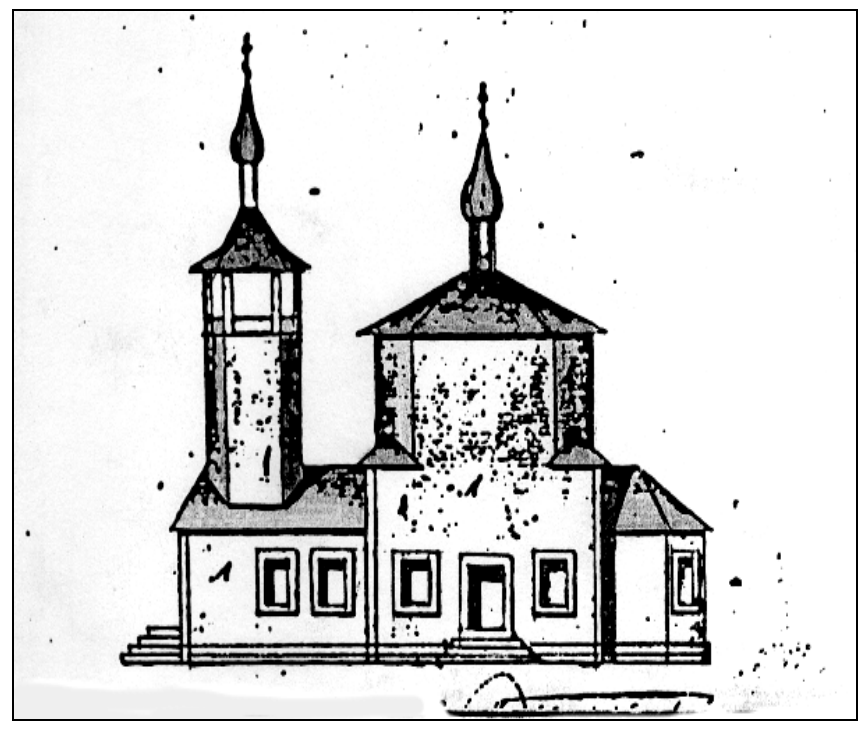

Fig.5. The Church in Kusa, the façade

A typical example is the Church in the village of Kusa. In this building, we can observe the following: an input room, a refectory and the main hall of the Church form a single frame; an altar is attached to the east wall (Fig. 5, 6). The wall with three apertures separates the refectory. In addition, the church building has three entrances [16].

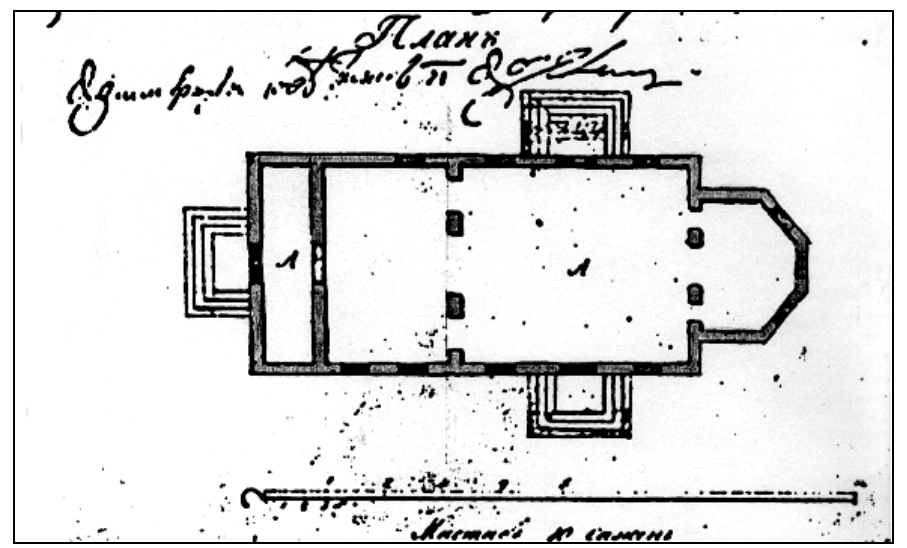

Fig.6. A plan of the Church in Kusa.

Evolution of the regional church design was interrupted by the arrival of the Soviet rule. In this period, directives coming from the Association of Soviet Architects, whose administration opinion was largely due to the governmental and party bodies and agencies, determined stylistic tendencies in architecture. New churches were not built at that time. Demolition and barbaric re-planning/conversion of ecclesiastical buildings contributed to the distortion of the historic architectural environment in towns and cities. Professional architects had been gradually but steadily losing their knowledge of general norms and rules of church construction along with the traditions of regional ecclesiastical architecture. 


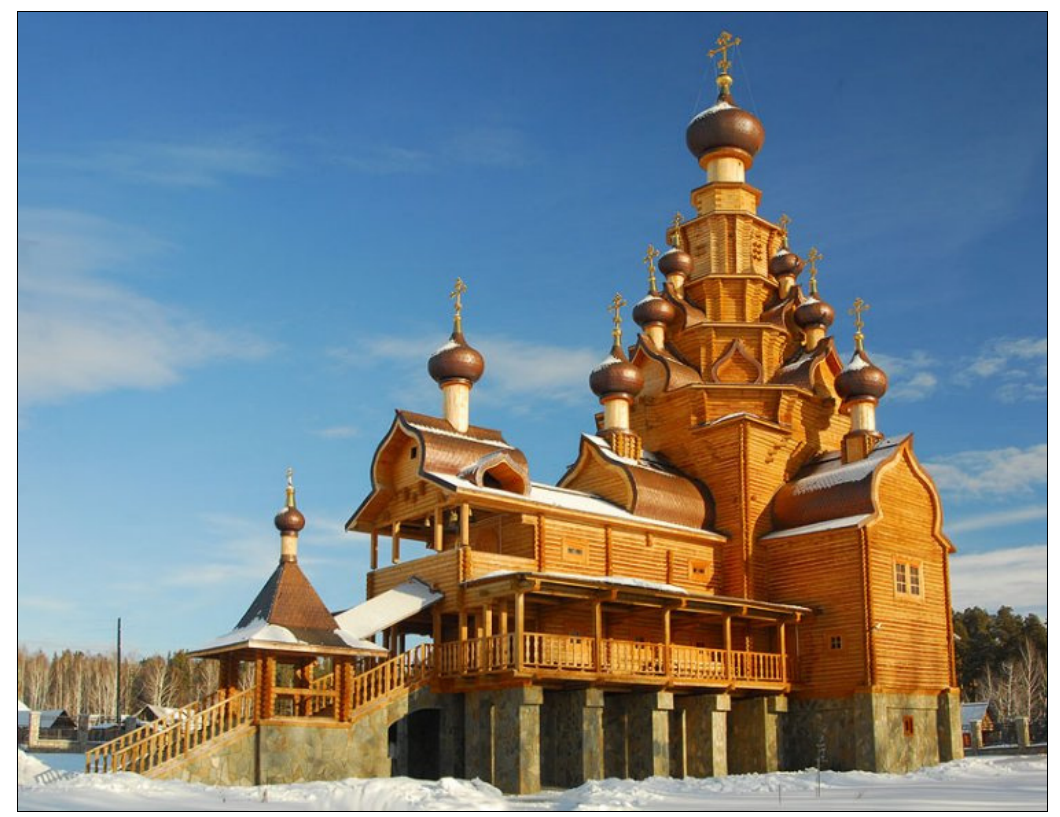

Fig.7. Church of the Icon of Mother of God 'Quick to Hearken' in Verkhnyaya Sanarka village. Built in 2005. Architect A.N. Obolenskiy. Photograph by E.V. Ponomarenko

Beginning in the last decade of XX c., the Russian society came to a revival of their interest in church architecture. Currently, the architectural school of the South Urals which is gradually shaping itself, requires for its successful evolution more research of and reliance on regional architectural and town-planning traditions in what pertains to new housing developments and, specifically, to the reconstruction of historical zones and environments within modern settlements. Insufficient continuity in architecture is what may lead to the loss of historically distinctive features by our towns and cities.

Today, stylization is a method most widely used in the region for the purposes of drawing on the historical architectural heritage in new development projects. The traditional Russian wooden architecture (structures from tree logs) is also being rather widely imitated by way of stylization. 


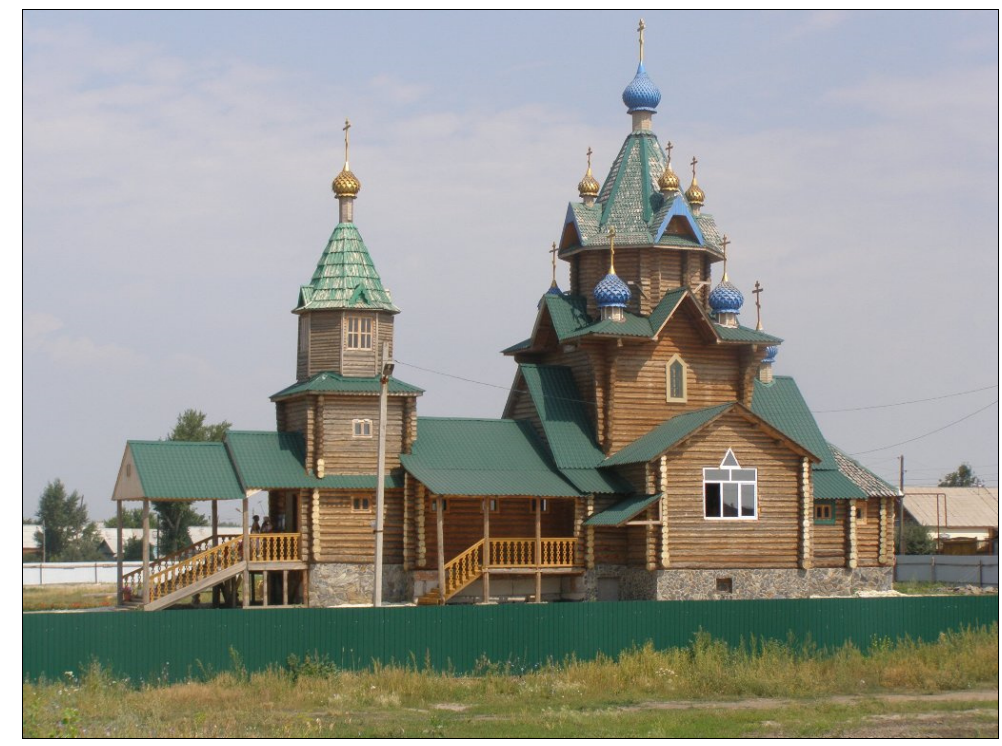

Fig. 8. Church of the Mantle of our Lady, Yuzhnouralsk town. Built in 2008. Architect N.S. Akchurina. Photograph by E.V. Ponomarenko

A very characteristic specimen of this variety is the church of the Icon of Mother of God 'Quick to Hearken' in a settlement called Verkhnyaya Sanarka, Troitsky district, Chelyabinsk region. The Transfiguration Church in the historical village of Kizhy was used as a model for it (Fig. 7). The main construction material used for the church of the Icon of Mother of God 'Quick to Hearken' were pine logs cut in the Urals. The part of the building that is most close to the model/prototype is the main log structure of the church for which no nails were used. In shape it is cruciform. In the western part of the church are the refectory and the bell-tower. The church has a conical vertical structure comprising a square piece and several octagonal ones with superimposed rounded gable heads and cupolas.

Various stylizations of the regionally peculiar three-part church design are used most frequently in wooden architecture. A characteristic specimen of that is the Church of the Mantle of our Lady in the town of Yuzhnhouralsk, Chelyabinsk region (Fig. 8).

The striving of people of very different prosperity to build new churches is what invests the whole story with a lot of optimism because in the situation when government policies and laws on cultural heritage protection and conservation are inefficient, the building of churches and attempts to find a new regional model for ecclesiastical architecture is what contributes significantly to the elevation of moral standards and revival of cultural authenticity of the region.

\section{Discussion}

Today, there are only a few studies focused on religious heritage and modern churches. These are mostly area studies not specifically concentrated on church architecture. The most interesting works are by authors I.V. Degtyarev and V.S. Bozhe [17], V.I. Konyuchenko [18], V.D. Olenkov [19], and others offering materials and data on individual architectural landmarks. Most interesting and insightful are the works by clerics. This is, for instance, a book by G.E. Gorlov and O.Yu. Bobrov «Spiritual vineyard of the Orenburg region» [20] where building designs and drawings are given. N.E. Stremsky "Martyrs, 
confessors and churches of the Orenburg Eparchy in the 20th c", contains interesting facts in the work. [21].

\section{Conclusion}

Generally, it is a peculiar characteristic of the modern architecture that the potent grassroots aspiration to revive the genius loci, deep-rooted ethnic traditions and culture, comes into conflict with insufficient professional expertise and experience. What we are witnessing now is a trend to restore historical architectural forms within the framework of amateurish building practices, particularly so in smaller settlements. The problems of professional church building are similar to the problems of renovation/restoration in the region: eclecticism of design caused by insufficient knowledge; the use of compositional, planning and decorative solutions improper to the functions of a particular building; involvement of construction and finishing materials that are not organic to the building; inappropriate colour layouts.

\section{Recommendations}

Religious buildings are currently test site for regional characteristics of architecture formation. Through religious architecture, ethnic groups are aware of their cultural and religious identity. Currently, the process of forming a regional variant of religious architecture in its infancy. At the break of tradition of temple construction, style is forming gradually. Since the churches are always accents in buildings, these searches are especially diverse. Often not regional patterns are quoted and styled, but the world ones.

The result of all these factors is the appearance in the region distinctive architectural style of religious architecture. Further investigation of the revealed new architectural style in its development will allow characterizing the developing regional features of the new Orthodox architecture.

\section{References}

1. N.M. Chernavskiy, The Orenburg Eparchy in its past and present, 1, (1900)

2. N.M. Chernavskiy, The Orenburg Eparchy in its past and present, 2, (1902)

3. I.P. Krechetovich, Setting up of the Eparchy in Orenburg, (1901)

4. P.I. Rychkov, The Orenburg Province Topographies (1887)

5. P.S. Pallas, Travels in different provinces of the Russian State, 2, (1786)

6. L.S. Sukhodol'skiy, The spread of Christianity in the Urals Region, 14, 53-54 (1854)

7. I.I. Arkhangelskiy, Materials for the history of the Troitsk town, 6(29), 5-51 (1900)

8. V.M. Cheremshanskiy, Description of the Orenburg Province (1859)

9. R.G. Ignatev, The Ufa Province's Memorandum Book, 2, (1873)

10. F.M. Starikov., Essays on the history and statistics of the Orenburg Cossack Host, (1891)

11. R.A. Budrina, The Hodegetria Nunnery in Chelyabinsk, (1904)

12. Daft of a wooden church for the Orenburg Defence Line, (Unpublished). Russian State Historical Archive

13. Plan and facade of a stone foundation of a wooden church for the Orenburg Defence line, (Unpublished). Russian State Historical Archive, Plans and drawings of civil architecture 
14. Street map of Chelyabinsk (Unpublished). Russian State Military History Archive, Military Science Archive

15. Synod decrees in 1826 and 1828, (Unpublished). Russian State Historical Archive

16. Russian State Archive of Ancient Documents 171

17. I.V Degtyarev, V.S. Bozhe,. Domes over the City (1992)

18. V. I. Konyuchenko, Chelyabinsk clergymen before the Revolution, 88-90 (1993)

19. V.D. Olenkov, Eastern Orthodox churches in the Chelyabinsk Region. History and Architecture (2008)

20. G.E.Gorlov, O.Bobrov, Spiritual Vineyard of the Orenburg Region (2009)

21. N.E. Stremskiy, Martyrs, confessors and churches of the Orenburg Diocese of $20^{\text {th }}$ c., 2, (1999) 